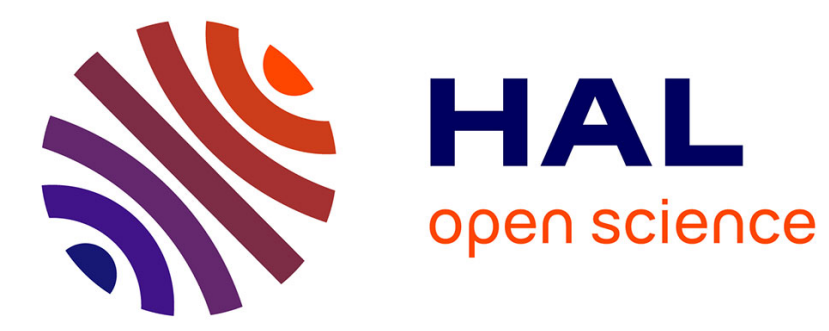

\title{
Entrepreneurship and Culture
}

Roy Thurik, Marcus Dejardin

\section{To cite this version:}

Roy Thurik, Marcus Dejardin. Entrepreneurship and Culture. Marco van Gelderen, Enno Masurel. Entrepreneurship in Context, Routledge, pp.175-186, 2012, Routledge Studies in Entrepreneurship, 978-0-415-89092-2. halshs-00943684

\section{HAL Id: halshs-00943684 https://shs.hal.science/halshs-00943684}

Submitted on 8 Feb 2014

HAL is a multi-disciplinary open access archive for the deposit and dissemination of scientific research documents, whether they are published or not. The documents may come from teaching and research institutions in France or abroad, or from public or private research centers.
L'archive ouverte pluridisciplinaire HAL, est destinée au dépôt et à la diffusion de documents scientifiques de niveau recherche, publiés ou non, émanant des établissements d'enseignement et de recherche français ou étrangers, des laboratoires publics ou privés. 


\title{
Entrepreneurship and Culture
}

\author{
Roy Thurik and Marcus Dejardin
}

\section{Introduction}

It is well-known that the level of entrepreneurial activity, for instance as expressed as the percentage of owner/managers of businesses relative to the labor force, differs strongly across countries (Van Stel 2005). This variation is related to differences in levels of economic development, and also to diverging demographic, cultural and institutional characteristics (Blanchflower 2000; Wennekers 2006). There is evidence of a U-shaped relationship between the level of business ownership (self-employment) and per capita income (Carree, Van Stel, Thurik and Wennekers 2002; Wennekers, Van Stel, Carree and Thurik 2010). Recent research within the framework of the Global Entrepreneurship Monitor (GEM) using the rate of nascent entrepreneurship or the prevalence of young enterprises shows the same phenomenon (Wennekers, Van Stel, Thurik and Reynolds 2005; Van Stel, Carree and Thurik 2005; Suddle, Beugelsdijk and Wennekers 2010). The meaning of this U-shape is much disputed because it is merely a stylized fact awaiting an explanation using the double causal relationship between entrepreneurship (indicated by business ownership rates, self-employment rates or nascent entrepreneurship rates) and the level of economic development (Thurik, Carree, Van Stel and Audretsch 2008). Nascent entrepreneurship also reveals a wide-ranging diversity across nations and even regions. An explanation for this variation is needed as many governments attach high hopes to the positive effect of entrepreneurship on economic growth and, as a consequence, try to promote new business start-ups.

Whereas a number of individually relevant determinants of entrepreneurship have been widely explored (Grilo and Thurik 2008; Parker 2009), differences across countries remain unexplored. There is a general feeling that whereas intertemporal differences can be attributed to economic effects such as per capita income and to technological developments, contemporaneous differences are of a mainly institutional or cultural nature. In other words, the relative stability of differences in entrepreneurial activity across countries suggests that factors other than economic ones are at play (Freytag and Thurik, 2010). Cultural factors, as a subset of stable contextual factors, may play a role. In this paper, we give examples of various theories on the relationship between cultural values and entrepreneurship, providing both a conceptual basis and an empirical test.

\section{Cultural values and entrepreneurial behavior}

As we explain below, there is no generally accepted interpretation of culture as a determinant of entrepreneurship. Neither is there a generally accepted definition for entrepreneurship (see Wennekers and Thurik [1999] for an overview). In the paper at hand, we adopt a pragmatic approach by equating entrepreneurship, business ownership and self-employment, and thus understand an entrepreneur to be the owner/manager of either an unincorporated or an incorporated business.

Because extensive research at the individual level of analysis shows a link between values, beliefs and behavior, it is plausible that the differences in national culture in which these values 
and beliefs are imbedded, may influence a wide range of behaviors, including the decision to become self-employed rather than to work for others (Mueller and Thomas 2000). Using this logic, several studies have explored the relationship between various aspects of culture and entrepreneurial behavior across cultures (McGrath and MacMillan 1992; Busenitz, Gómez and Spencer 2000; Lee and Peterson 2000; Mueller and Thomas 2000; Stephan and Uhlaner 2010; Autio, Pathak and Wennberg 2010). The remainder of this section initially introduces four schools of thought, related to culture, which may explain entrepreneurial prevalence. We then try to relate these to the notion of push-versus-pull factors as influences on entrepreneurship.

The aggregate psychological traits perspective explains differences in rates of entrepreneurial activity as follows: If there are more people with entrepreneurial values in a country, there will be an increased number of people displaying entrepreneurial behaviors (Davidsson 1995).

Inglehart $(1990 ; 1997 ; 2003)$ uses the concept of post-materialism to explain observed changes in values in modern societies. More generally, it describes the transformation in many countries from a culture dominated by materialistic-oriented individuals to a society in which an increasing proportion of the population favors non-materialistic life-goals over materialistic ones. Below, it is argued that a society that is more post-materialist is likely to be less entrepreneurial. This concept comes close to the aggregate psychological trait perspective but does not refer to a value or a treat but rather describes how a society should behave. Its operationalization is complex and heterogeneous.

The social legitimation or moral approval of entrepreneurship focuses on the impact of social norms and institutions on society-at-large (Etzioni 1987). This view claims that greater rates of entrepreneurship are found in societies where the entrepreneur is endowed with higher social status, attention to entrepreneurship is paid within the educational system, and more tax incentives exist to encourage business start-ups. This results in a higher demand for and supply of entrepreneurship (Etzioni 1987). Although the direction of the predictions are the same for the social legitimation and aggregated psychological traits perspectives, the explanations differ. Thus, in the social legitimation view, the effect is due to institutional and cultural influences, whereas in the aggregated psychological traits view, the effect is due to the aggregated effects of individual characteristics. For instance, in the social legitimation view, more individuals value entrepreneurship as a result of the higher social status conferred on entrepreneurs in certain societies, whereas in the aggregated psychological traits view, the average person simply indicates that he holds entrepreneurs in high esteem. Although the theoretical explanations may differ, it may be difficult, especially at the macro level, to empirically test which of these explanations is correct as cultural indices are drawn from aggregating responses by individuals.

The dissatisfaction perspective is an entirely different approach when compared to the first three approaches. As we argue in our dissatisfaction section, this macro level explanation for entrepreneurship assumes that variation in entrepreneurship is based upon differences in values and beliefs between the population as a whole and potential entrepreneurs. Thus, in a predominantly non-entrepreneurial culture, a clash of values between groups may drive would-be entrepreneurs into self-employment (Baum, Olian, Erez, Schnell, Smith, Sims, Scully and Smith 1993: 505). The predicted relationship between the cultural indicators and entrepreneurship according to the dissatisfaction hypothesis is thus the opposite of that which might be expected according to the aggregate psychological trait or the social legitimation views.

Applicable to both economic and cultural factors is the notion of supply, or push, and demand, or pull, factors for business start-up and entrepreneurship in general (Thurik, Carree, Van Stel and Audretsch 2008; Stephan and Uhlaner 2010). Pull factors relate to the expectation of being better-off as an entrepreneur. Thus, individuals are often attracted to entrepreneurship, with the expectation that it will provide greater material and/or non-material benefits. Push factors take into account the conflict between one's current and one's desired state. Push factors are often 
associated with some level of dissatisfaction. It is not easy to classify the four schools of thought according to the push or pull view although post-materialism seems to lean towards pull factors whereas dissatisfaction adopts more of a push 'flavor'. This difficulty in classifying cultural elements in a supply vs. demand view - as is standard procedure in economic modeling - is one of the reasons why combining cultural and economic variables to explain entrepreneurship is substantially underdeveloped (Thurik 2009).

The remainder of this paper proceeds as follows. The post-materialism approach is illustrated in the section based upon Uhlaner and Thurik (2007). Following that, the dissatisfaction approach is illustrated based upon Noorderhaven, Thurik, Wennekers and Van Stel (2004). Finally, the aggregate psychological traits approach is illustrated by research on uncertainty avoidance based upon Wennekers, Thurik, Van Stel and Noorderhaven (2007). We do not present evidence of the social legitimation or moral approval of entrepreneurship approach here. These can be found in the literature on institutions and entrepreneurship (Baumol 1990; Busenitz, Gomez and Spencer 2000; Djankov, La Porta, Lopez-de-Silanes and Shleifer 2002; Bowen and De Clercq 2008; Freytag and Thurik 2010; Henrekson and Sanandaji 2010).

\section{Post-materialism and entrepreneurship}

Although less frequently used in macro-economic research as a predictor of economic activity than the cultural indices developed by Hofstede (1980), Inglehart's (Inglehart 1990; 1997; 2003) work on post-materialism as a cultural attribute is well established. Inglehart uses the concept of postmaterialism to help explain observed changes in values in modern societies. More generally, the post-materialism hypothesis describes the transformation in many countries from a culture dominated by materialistic-oriented individuals to a society where an increasing proportion of the population favors non-materialistic life-goals over materialistic ones.

The hypothesis of post-materialism is based on two sub-hypotheses, that of socialization and that of scarcity. The socialization hypothesis assumes that one's values reflect, to a great extent, the prevailing circumstances during the formative years. The scarcity hypothesis assumes that an individual's priorities reflect their socio-economic circumstances; they therefore attach the greatest value to relatively scarce goods (Inglehart 1990; 1997). Taken together, these two hypotheses imply that, as a consequence of the unprecedented prosperity and the absence of war in Western countries since 1945, younger birth cohorts attach less importance to economic and physical security (materialistic values) than older birth cohorts who experienced poverty (and/or other ravages associated with war) in their early years. Instead, younger birth cohorts ascribe a higher priority to non-material goals such as esteem, self-realization and quality of life (post-materialist values), often referred to in psychology literature as Maslow's 'higher order needs' (Maslow 1954).

In his research, Inglehart's (1990) findings support the conclusion that the primary reason for the shift toward post-materialism is intergenerational replacement, and not changes in values to individuals within their own life spans. A consequence of this shift is a declining emphasis on economic growth in these countries, together with an increasing emphasis on the protection of the environment and the quality of life. Other research on post-materialism shows that, in countries with a prevailing post-materialist climate, the emphasis on income attainment is less significant than in materialistic countries (De Graaf 1988), supporting Inglehart's description of postmaterialist cultures as 'economic underachievers'. More recent research shows that the trend toward post-materialism may be declining (Van Deth 1995). Regardless of direction, the bulk of the research shows that these values are very slow to change within particular cultures.

Furthermore, as noted in the introduction, research by Inglehart (1990) supports the view that postmaterialism is only partly influenced by economic climate. 


\section{Testing the influence of post-materialism on entrepreneurship}

Non-material motives for entrepreneurs notwithstanding, Uhlaner and Thurik (2007) conclude that: a) material gains are central or crucial to entrepreneurship; and b) because those gains, by definition, are of less value to post-materialist individuals, a society that is more post-materialist is likely to be less entrepreneurial. They use data from different sources, including the Global Entrepreneurship Monitor (GEM), World Value Surveys, and the World Development Indicators database of the World Bank. The measure for post-materialism is based upon Inglehart's four-item post-materialism index (ICPSR, 1994). The measures for entrepreneurship are total entrepreneurial activity measured as a combination of nascent entrepreneurship (the $\%$ of people in the age group of 18 to 64 years who are actively engaged in the start-up process) or new business formation (those owning and managing a business less than 42 months old expressed in \% of adults in the same age group). Twenty-seven countries had complete data, including Argentina, Belgium, Brazil, Canada, Chile, China, Denmark, Finland, France, Germany (Western), Hungary, India, Ireland, Italy, Japan, Korea, Mexico, Norway, Poland, South Africa, Slovenia, Spain, Sweden, Switzerland, the Netherlands, the United Kingdom and the United States.

The results of Uhlaner and Thurik (2007) confirm the importance of post-materialism when explaining total entrepreneurial activity, and new business formation in particular. The negative relationship between post-materialism and entrepreneurship is also evident when controls are used. However, a certain lack of stability within the findings suggests rather complex interrelationships between the controls and post-materialism. One possibility is that post-materialism mediates the relationship between per capita income and total entrepreneurial activity, consistent with Ingelhart's conclusions that economic climate drives social change, rather than the reverse (Inglehart 1990).

\section{Dissatisfaction and entrepreneurship}

Various types of dissatisfaction are used in micro studies of entrepreneurship. Brockhaus (1980) states that dissatisfaction with previous work experience is closely related to the 'entrepreneurial decision'. He finds that self-employed individuals tend to be relatively highly dissatisfied with the previous work itself, with supervision and with opportunities for promotion (but more satisfied with actual pay). Shapero and Sokol $(1982 ; 79)$ assert, "Research data show that individuals are much more likely to take action upon negative information rather than positive, and the data on company formations support that conclusion". In their final model both pull and push factors contribute to the start-up of a business, but negative 'displacements' such as forced emigration, being fired and being bored or angered predominate. Dyer (1994: 10) cites several other studies showing that people are more likely to start their own enterprises when they face a lack of opportunities for viable careers in existing organizations.

This fits with what psychology tells us about motivation. Individuals with a high sense of self-efficacy, in particular, are activated by self-dissatisfaction, i.e., when they do not attain their goals. This spurs efforts to align outcomes with their value standards (Bandura and Cervone 1983). Vroom (1982: 175) infers from his model "... that job satisfaction should be related to the strength of the force on the person to remain in his job" or, in other words, "... that job satisfaction and turnover are negatively related to one another". Consequently, it is no surprise that dissatisfaction is one of the most important predictors of job mobility (Vroom 1982). Hence, at the level of the individual, various kinds of dissatisfaction are conducive to job mobility and the propensity to become self-employed.

It is tempting to generalize these findings at the country level. However, a positive correlation between dissatisfaction and self-employment at the country level may also originate from self-employed people being relatively dissatisfied with their lives. This reversed causality, self-employment causing low satisfaction, is however ruled out by ample empirical evidence. In many studies (Benz and Frey, 2008a, 2008b; Blanchflower and Oswald 1998; Bradley and Roberts 
2004) the job satisfaction of the self-employed is, on average, found to be higher than, or at least equal to, that of salaried employees. These studies report that the self-employed (and entrepreneurs, as a subgroup of the self-employed) have higher work satisfaction than the employed. This seems to be the case despite longer work hours, poorer working conditions, heightened job stress and higher risk (Bradley and Roberts 2004). Apparently, these are compensated by other factors such as autonomy and the possibility of becoming wealthy. Given the strong positive correlation between dissatisfaction and self-employment at the country level, it is likely that the 'push' effect of actual dissatisfaction on the number of business start-ups is enhanced by the 'pull' or demonstration effect of the self-employed being relatively satisfied with their businesses, boosting the anticipated satisfaction of entrepreneurship.

\section{Testing the influence of dissatisfaction on entrepreneurship}

Noorderhaven, Thurik, Wennekers and Van Stel (2004) conclude that higher levels of dissatisfaction with life in a country is conducive to higher rates of self-employment whereas higher levels of prosperity lead to lower rates of self-employment. The dependent variable is the number of self-employed (excluding agriculture, hunting, forestry and fishing), divided by the total labor force of a country. Labor income share, unemployment, earning differentials, female labor participation and population density are used as controls. Data is used from various sources, such as Compendia 2000.2 (EIM), OECD Labour Force Statistics, OECD National Accounts, Eurobarometer, etc. An unbalanced panel of 48 observations (15 European countries in 1976, 1984, 1990 and 1998) is available for testing. The conclusion of this exercise is that countries with relatively more people who are dissatisfied with the society they live in and/or who have a lower overall life satisfaction, have a higher proportion of self-employed. This conclusion is robust when controlling for other explanatory variables. In addition to the positive influence of dissatisfaction, a negative influence of the level of economic development is found. The fact that nations with a higher average level of dissatisfaction have a higher proportion of self-employed should not be taken as a sign that the average self-employed is more dissatisfied than the average wageemployed individual. The conclusion to be drawn is that if more people in a country feel dissatisfied with their life and with the way democracy works, this increases the chance that they will seek self-employment. Those who do so tend to improve their life and job satisfaction over those who do not (Hofstede 1998).

\section{Uncertainty avoidance and entrepreneurship}

Attitudes, such as risk aversion, pertain to individuals and may vary widely within groups. At the level of nations, cultural traits related to these individual psychological traits may be distinguished. Empirically, these traits may be derived as mean, modal or extreme values of individual observations or through a direct analysis of 'ecological data' (pertaining to national practices and achievements). Cultural traits - or aggregated psychological traits - represent a nation's 'mental programs' that are developed in socialization processes in the family in early childhood and reinforced in schools and organizations (Hofstede 2001: xix). Accordingly, cultural traits may differ between societies.

A cultural trait strongly associated with individual attitudes towards risk and uncertainty is 'uncertainty avoidance'. According to Hofstede, uncertainty avoidance relates to the extent to which societies tolerate ambiguity (Hofstede 2001: 146). A culture is characterized by high uncertainty avoidance when its members feel threatened by uncertain or unknown situations. People in these cultures: "look for structure in their organizations, institutions and relationships, which makes events clearly interpretable and predictable" (Hofstede 2001: 148). In countries with lower uncertainty avoidance: "not only familiar but also unfamiliar risks are accepted, such as changing jobs and starting activities for which there are no rules" (Hofstede 2001: 148). Low uncertainty avoidance thus implies a "willingness to enter into unknown ventures" (Hofstede 2001: 164). Hofstede operationalizes uncertainty avoidance using three survey questions about 
whether employees feel "company rules should not be broken even when the employee thinks it is in the company's best interests" (Hofstede 2001: 148), about their personal expected job stability and about how often they feel nervous or tense at work.

\section{Testing the influence of uncertainty avoidance}

Wennekers, Thurik, Van Stel and Noorderhaven (2007) have tested the direct and the indirect contribution of uncertainty avoidance to the variance in business ownership across nations and over time. They use several controls, such as level of economic development, share of services, relative earnings of self-employed, unemployment, social security entitlements, income disparity, financial variables and demographic characteristics. A panel data set is constructed for 21 OECD countries for 1976, 1990 and 2004. Many different data sources are used, the uncertainty avoidance data is from Hofstede (2001) and the entrepreneurship variable is the percentage of business owners in the labor force.

A positive direct influence of uncertainty avoidance on business ownership rates has been found, indicating that, in the years 1976 through 2004, a climate of high uncertainty avoidance in existing firms and organizations may have pushed enterprising individuals towards selfemployment (in line with Baum et al., 1993). These findings also show that a personal trait (risk aversion) and its cultural counterpart (uncertainty avoidance) may have a diverging impact on entrepreneurship. Repeating the regressions in three separate sample years confirms these results for 1976 and 1990. However, for 2004, the main outcome is that uncertainty avoidance no longer has any direct influence on business ownership. The interpretation of Wennekers, Thurik, Van Stel and Noorderhaven (2007) is that the advent of the entrepreneurial economy (Audretsch and Thurik 2001) has created pull factors mobilizing the relatively abundant supply of potential entrepreneurial capital in countries with low uncertainty avoidance. Evidence is also found for a negative indirect influence of uncertainty avoidance through a moderating effect on the influence of per capita income on business ownership. In low uncertainty avoidance countries, the negative influence of per capita income on the rate of business ownership is clearly smaller than in high uncertainty avoidance countries. In a group of eight high-uncertainty avoidance countries, a relatively strong negative relationship between GDP per capita and the level of business ownership suggests that rising opportunity costs of entrepreneurship are the dominant perception in this cultural environment. On the other hand, in a group of thirteen low-uncertainty avoidance countries, the relatively weak negative relationship between business ownership and per capita income suggests that rising opportunities are a countervailing force in an environment of low uncertainty avoidance.

\section{Concluding remarks}

The notion of patterns of values which shape human behavior is common to different definitions of culture (Kroeber and Parsons 1958; Hofstede 1980). Sometimes the view is taken that cultural values are typically determined early in life (Hofstede 1980) and tend to endure over time (Hofstede 1980; Mueller and Thomas 2000). Other researchers assume that, although certain values may prevail in a particular culture at a moment in time, shifts may take place over time, from generation to generation, particularly in societies undergoing radical industrial transformation. For instance, Inglehart examines the shift among Americans and West Europeans toward post-materialism between 1970 and 1988 (Inglehart 1990). Even if these shifts take place, they are expected to move slowly. Hence, it should come as no surprise for scholars examining the context of entrepreneurial activities, that cultural values are candidates for explaining persistent differences between levels of entrepreneurship between countries. This paper aims to show how theories such as the post-materialism approach, the dissatisfaction approach and the aggregate psychological traits approach may help in contrasting and explaining the relationship between cultural values and entrepreneurship. Examples of all three theories are given including a conceptual framework and an, albeit basic, empirical test. 
Despite increasing empirical interest for the topic of the influence of culture on entrepreneurship (Acs and Szerb 2010; Autio, Pathak and Wennberg 2010; Freytag and Thurik 2010; Henrekson and Sanandaji 2010; Stephan and Uhlaner 2010), the limitations of the recent exercises on the relationship between cultural values and entrepreneurship remain clear. Although more and more individual data is used, the low number of available aggregate data points makes a serious test of which cultural variables have an effect very difficult. This is frustrating given the richness of ideas about the cultural influences on the level of entrepreneurship. This frustration is bound to persist for three reasons. Firstly, even if when it takes place, cultural shifts move very slowly so a time dimension will not easily contribute to the number of data points. Secondly, schools of thought about the meaning and content of cultural variables come with their own independent data sets that usually have different constraints and a lack of overlap hampers a fair testing exercise. Thirdly, cultural variables are difficult to classify in the usual supply vs. demand set-up of economic models (Thurik 2009). Despite these limitations, there is general agreement that we cannot simply state, when explaining levels of entrepreneurship, that culture is the residue when economic variables and regulator arrangements have had their say (Djankov, La Porta, Lopez-de-Silanes and Shleifer 2002; Van Stel, Storey and Thurik 2007; Bowen and De Clercq 2008).

Acknowledgements: the present paper attempts to combine the ideas and results of some earlier papers, such as Noorderhaven, Thurik, Wennekers and Van Stel (2004), Uhlaner and Thurik (2007), Wennekers, Thurik, Van Stel and Noorderhaven (2007) and Freytag and Thurik (2007 and 2010). Assistance by Adam Lederer, Marco van Gelderen, Frank Janssen, Erik Swets, Lorraine Uhlaner and Sander Wennekers is gratefully acknowledged. This paper is written in cooperation with the research program SCALES, carried out by EIM/Panteia and financed by the Dutch Ministry of Economic Affairs. It benefitted from visits by Marcus Dejardin and Roy Thurik to CRECIS (Centre for Research in Entrepreneurial Change and Innovative Strategies), Louvain School of Management, to EM-Lyon and to CREM, UFR Sciences Economiques et de Gestion, Université de Caen Basse-Normandie.

\section{References}

Acs, Z.J., \& Szerb, L. (2010). The link between culture and entrepreneurship: Universal values, institutional characteristics and individual features. Paper presented at the GEM scientific conference, Imperial College London, 30 September-2 October.

Audretsch, D.B., \& Thurik, A.R. (2001). What is new about the new economy: sources of growth in the managed and entrepreneurial economies. Industrial and Corporate Change, 10(1), 267315.

Autio, E., Pathak, S., \& Wennberg, K. (2010). Culture's consequences for entrepreneurial behaviours. Paper presented at the GEM scientific conference, Imperial College London, 30 September-2 October.

Bandura, A., \& Cervone, D. (1983). Self-evaluative and self-efficacy mechanisms governing the motivational effects of goal systems. Journal of Personality and Social Psychology, 45(5), 1017-1028.

Baum, J.R., Olian, J.D., Erez, M., Schnell, E.R., Smith, K.G., Sims, H.P., Scully, J.S., \& Smith, K.A. (1993). Nationality and work role interactions: a cultural contrast of Israeli and US entrepreneurs' versus managers' needs. Journal of Business Venturing, 8(6), 499-512.

Benz, M., \& Frey, B.S. (2008a). Being independent is a great thing: Subjective evaluations of selfemployment and hierarchy. Economica, 75, 362-383.

Benz, M., \& Frey, B.S. (2008b). The value of doing what you like: evidence from the selfemployed in 23 countries. Journal of Economic Behavior and Organization, 68, 445-455. 
Blanchflower, D.G. (2000). Self-employment in OECD countries. Labor Economics, 7(5), 471505.

Blanchflower, D.G., \& Oswald, A.J. (1998). What makes an entrepreneur? Journal of Labor Economics, 16(1), 26-60.

Baumol, W.J. (1990). Entrepreneurship: productive, unproductive, and destructive. Journal of Political Economy, 98(5), 893-921.

Bowen, H.P., \& De Clercq, D. (2008). Institutional context and the allocation of entrepreneurial effort. Journal of International Business Studies, 39(4), 747-767.

Bradley, D.E., \& Roberts, J.A. (2004). Self-employment and job satisfaction: investigating the role of self-efficacy, depression, and seniority. Journal of Small Business Management, 42(1), 3758 .

Brockhaus, R.H. (1980). The effect of job dissatisfaction on the decision to start a business. Journal of Small Business Management, 18(1), 37-43.

Busenitz L.W., Gomez, C., \& Spencer, J.W. (2000). Country institutional profiles: unlocking entrepreneurial phenomena. Academy of Management Journal, 43(5), 994-1003.

Carree, M.A., van Stel, A.J., Thurik, A.R., \& Wennekers, A.R.M. (2002). Economic development and business ownership: an analysis using data of 23 OECD countries in the period 1976-1996. Small Business Economics, 19(3), 271-290.

Davidsson, P. (1995). Culture, structure and regional levels of entrepreneurship. Entrepreneurship and Regional Development, 7(1), 41-62.

De Graaf, N.D. (1988). Postmaterialism and the stratification process: An international comparison. Utrecht: ISOR.

Djankov, S., La Porta, R., Lopez-de-Silanes F., \& Shleifer, A. (2002). The regulation of entry. Quarterly Journal of Economics, 117(1), 1-35.

Dyer, W.G. (1994). Toward a theory of entrepreneurial careers. Entrepreneurship Theory and Practice 19(2), 7-21.

Etzioni, A. (1987). Entrepreneurship, adaptation and legitimation. Journal of Economic Behavior and Organization, 8(2), 175-189.

Freytag, A., \& Thurik, A.R. (2007). Entrepreneurship and its determinants in a cross-country setting. Journal of Evolutionary Economics, 17(2), 117-131.

Freytag, A., \& Thurik, A.R. (2010). Entrepreneurship and culture. New York: Springer.

Grilo, I., \& Thurik, A.R. (2008). Determinants of entrepreneurial engagement levels in Europe and the US. Industrial and Corporate Change, 17(6), 1113-1145.

Henrekson, M., \& Sanandaji, T. (2010). The interaction of entrepreneurship and institutions. IFN Working Paper No. 830, Research Institute of Industrial Economics, Stockholm.

Hofstede, G. (1980). Culture's consequences: international differences in work-related values. Cross cultural Research and Methodology Series 5. Newbury Park, CA: Sage Publications.

Hofstede, G. (1998). Entrepreneurship in Europe. Maastricht/House of Europe: Schuman Lecture, Studium Generale.

Hofstede, G. (2001). Culture's consequences; comparing values, behaviors, institutions and organizations across nations. 2nd edition. Thousand Oaks: Sage.

Inglehart, R. (1990). Culture shift in advanced industrial society. Princeton, NJ: Princeton University Press.

Inglehart, R. (1997). Modernization and post-modernization: cultural, economic and political change in 43 societies. Princeton, NJ: Princeton University Press.

Inglehart, R. (2003). Human values and social change: findings from the values surveys. Leiden, The Netherlands: Brill Publishers.

Inter-University Consortium for Political and Social Research (1994). World values survey 1981 1984 and 1990-1993 (codebook). Ann Arbor, MI: ICPSR.

Kroeber, A.L., \& Parsons, T. (1958). The concepts of culture and of social system. American Sociological Review, 23(5), 582-583. 
Lee, S.M., \& Peterson, S.J. (2000). Culture, entrepreneurial orientation, and global competitiveness. Journal of World Business, 35(4), 401-416.

Maslow, A. (1954). Motivation and personality. New York: Harper and Row.

McGrath, R.G., \& MacMillan, I.C. (1992). More like each other than anyone else? A crosscultural study of entrepreneurial perceptions. Journal of Business Venturing 7(5), 419-429.

Mueller, S.L., \& Thomas, A.S. (2000). Culture and entrepreneurial potential: a nine country study of locus of control and innovativeness. Journal of Business Venturing 16(1), 51-75.

Noorderhaven, N.G., Thurik, A.R., Wennekers, A.R.M., \& van Stel, A. (2004). The role of dissatisfaction and per capita income in explaining self-employment across 15 European countries. Entrepreneurship Theory and Practice, 28(5), 447-466.

Parker, S.C. (2009). The economics of entrepreneurship. Cambridge, UK: Cambridge University Press.

Shapero, A., \& Sokol, L. (1982). The social dimensions of entrepreneurship. In C.A. Kent, D.L. Sexton and K.H. Vesper (eds), Encyclopedia of Entrepreneurship (pp. 72-90). Englewood Cliffs, NJ: Prentice-Hall Inc.

Stephan, U., \& Uhlaner, L.M. (2010). Performance-based vs socially supportive culture: A crossnational study of descriptive norms and entrepreneurship. Journal of International Business Studies, 41(8), 347-1364.

Suddle, K., Beugelsdijk, Sj., \& Wennekers, S. (2010). Entrepreneurial culture and its effect on the rate of nascent entrepreneurship. In A. Freitag and R. Thurik (eds), Entrepreneurship and culture (pp. 227-244). New York: Springer.

Thurik, A.R., Carree, M.A., van Stel, A., \& Audretsch, D.B. (2008). Does self-employment reduce unemployment? Journal of Business Venturing, 23(6), 673-686.

Thurik, A.R. (2009). Entreprenomics: entrepreneurship, economic growth and policy. In Z.J. Acs, D.B. Audretsch and R. Strom (eds), Entrepreneurship, Growth and Public Policy (pp. 219249). Cambridge, UK: Cambridge University Press.

Uhlaner, L.M., \& Thurik, A.R. (2007). Post-materialism: a cultural factor influencing total entrepreneurial activity across nations. Journal of Evolutionary Economics, 17(2), 161-185.

Van Deth, J.W. (1995). De stabiliteit van oude en nieuwe politieke oriëntaties. In J.J.M. Van Holsteyn and B. Niemoller (eds), De Nederlandse Kiezer. Leiden: DWSO Press.

Van Stel, A. (2005). COMPENDIA: Harmonizing business ownership data across countries and over time. International Entrepreneurship and Management Journal, 1(1), 105-123.

Van Stel, A., Carree M.A., \& Thurik, A.R. (2005). The effect of entrepreneurial activity on national economic growth. Small Business Economics, 24(3), 311-321.

Van Stel, A., Storey, D., \& Thurik, A.R. (2007). The effect of business regulations on nascent to young business entrepreneurship. Small Business Economics, 28(2-3), 171-186.

Vroom, V.H. (1982). Work and Motivation. Malabar, Florida: Robert E. Krieger Publishing Company.

Wennekers, A.R.M. (2006). Entrepreneurship at Country level: Economic and Non-Economic Determinants. PhD thesis, Erasmus Research Institute of Management (ERIM), Rotterdam.

Wennekers, A.R.M., \& Thurik, A.R. (1999). Linking entrepreneurship and economic growth. Small Business Economics, 13(1), 27-55.

Wennekers, A.R.M., van Stel, A. J., Carree, M.A., \& Thurik, A.R. (2010). The relation between entrepreneurship and economic development: is it U-shaped? Foundations and Trends in Entrepreneurship, 6(3), 167-237.

Wennekers, A.R.M., van Stel, A.J., Thurik, A.R., \& Reynolds, P. (2005). Nascent entrepreneurship and the level of economic development. Small Business Economics, 24(3), 293-309.

Wennekers, A.R.M., Thurik, A.R., van Stel, A.J., \& Noorderhaven, N. (2007). Uncertainty avoidance and the rate of business ownership across 21 OECD countries, 1976-2004. Journal of Evolutionary Economics, 17(2), 133-160. 